\title{
Formation age of the Dahongliutan pegmatite type rare metal deposit in \\ Western Kunlun: evidence from muscovite ${ }^{40} \mathrm{Ar} /{ }^{39} \mathrm{Ar}$ isotopic dating
}

\author{
QIAO GENGBIAO $^{1 *}$, WU YUEZHONG ${ }^{1}$, LIU TUO $^{1}$
}

${ }^{1}$ Xi' an Center of China Geological Survey, Northwest China Center for Geoscience Innovation, Xi'an, 710054,

Shaanxi, P.R.China (*correspondence: qgb408@163.com)

${ }^{40} \mathrm{Ar} /{ }^{39} \mathrm{Ar}$ analysis procedure

Laser in-situ ablation technique was used for ${ }^{40} \mathrm{Ar} /{ }^{39} \mathrm{Ar}$ analyses. Firstly,All aliquots of samples with the international standard YBCs $(29.286 \pm 0.045 \mathrm{Ma})$ [1] were stacked in quartz vials. Neutron irradiation was carried out in position B4 of 49-2 Nuclear Reactor, Beijing (China), with a flux of $2.65 \times 10^{13} \mathrm{n}\left(\mathrm{cm}^{2} \mathrm{~s}\right)^{-1}$ for 24 hours. Secondly, Isotopic measurements were made on the Noblesse mass spectrometer at IGGCAS. Ca and $\mathrm{K}$ correction factors are $\left[{ }^{36} \mathrm{Ar} /{ }^{37} \mathrm{Ar}\right]_{\mathrm{Ca}}=$ $0.000261, \quad\left[{ }^{39} \mathrm{Ar} /{ }^{37} \mathrm{Ar}\right]_{\mathrm{Ca}}=0.000724, \quad\left[{ }^{40} \mathrm{Ar} /{ }^{39} \mathrm{Ar}\right]_{\mathrm{K}}=0.00088$. Ages were calculated using the decay constant $\left(5.543 \times 10^{-}\right.$ ${ }^{10} \mathrm{yr}^{-1}$ ) listed by Steiger et al. [2] and all errors were quoted at the $2 \sigma$ level. Plateau ages were determined from three or more contiguous steps, comprising $>50 \%$ of the ${ }^{39} \mathrm{Ar}$ released, revealing concordant ages at the $95 \%$ confidence level. The data were processed by using the York regression algorithm [3] and ArArCALC [4] .

Result and Conclusion

Using laser ablation technique, the authors obtained a muscovite ${ }^{40} \mathrm{Ar} /{ }^{39} \mathrm{Ar}$ plateau age of $144.7 \pm 4.3 \mathrm{Ma}$, and its total fusion dating is $144.0 \pm 3.8 \mathrm{Ma}$ (Figure 1). Because of the intrusive contact relationship between the Dahongliantan pegmatite veins and the host rock (formation age $220 \sim 208$ Ma) in Western Kunlun, the mineralization age should be no earlier than the Late Triassic. The argon isotope ages of muscovite determined in this paper are from Late Jurassic to Early Cretaceous, which is later than the formation age of strata and granitoids. Therefore, the age of diagenesis and mineralization of the Dahongliutan pegmatite type rare metal deposit is $144.7 \pm 4.3 \mathrm{Ma}$.

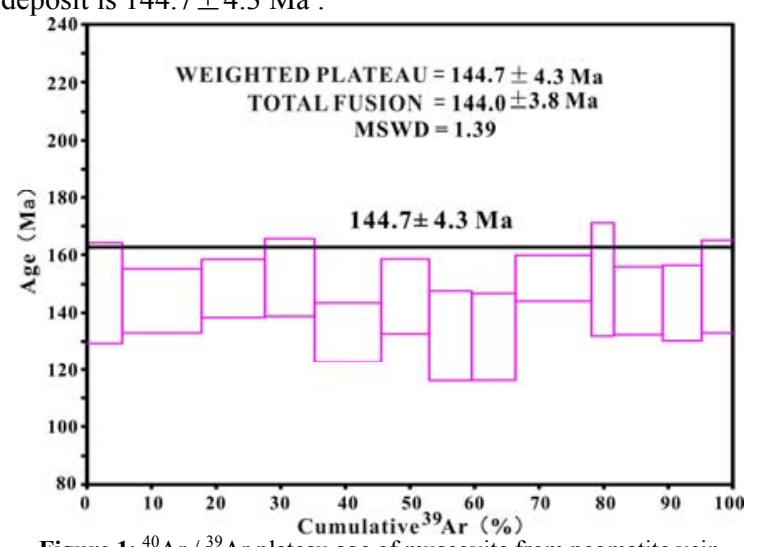

Figure 1: ${ }^{40} \mathrm{Ar} /{ }^{39} \mathrm{Ar}$ plateau age of muscovite from pegmatite vein [1]Wang Fei et al. (2014) Chemical Geology 388, 87-97. [2] Steiger \& Jäger (1977) EPSL 36, 359-362. [3] York (1969) EPSL 5,320-324. [4] Koppers (2002) Computers Geosciences 28, 605-619. 